\title{
Franciscan Friars and the Sworn Virgins of the North Albanian Tribes*
}

\author{
RENÉ GRÉMAUX
}

\section{Introduction}

With the approval of the Holy Catholic Church you, Nita Prenk Vukës, are from now on [puts hand in water and sprinkles Nita] Tani Prenk Vukës. In the name of the Father, the Son and the Holy Spirit.

So speaks a priest in the historical drama Nita by Josip Rela (d. 1986). The action takes place in the year 1729 in the author's native Arbanasi, a settlement near the Dalmatian port of Zadar, which three years earlier had been founded by Catholic Albanian refugees from the area between Lake Scutari and the Adriatic coast. Led by their archbishop, the refugees left the misery of their Turkish-ruled homeland and settled on Venetian territory. While still at home Nita had fallen in love with a young man. When she fled with her father Prenk Vukës and other villagers, her lover had to stay behind for the time being. On taking leave Nita had promised to wait for him abroad. At the age of 20 , when after three years of waiting she had lost all hope of seeing her beloved again, she decided to proclaim herself a male. To her father, who wanted her to marry someone else, the attractive protagonist explained that her intention was 'to stop declarations of love, the attentions of suitors'. In the end her father gave his approval and after a public interrogation of Nita by the priest and the council of village elders in order to ascertain that no pressure was being put on her, these authorities and the local Venetian administrator endorsed her decision. She was asked what name she wanted to adopt as a male; she chose witnesses; and the priest carried out the above-mentioned ritual in the open air. The onlookers then presented the new male with appropriate garments, and the governor gave him a new gun - the ultimate sign of masculinity.

Unfortunately, Rela's source for his story of a priest blessing a woman who has chosen to live as a man is a mystery. In my view, poetic licence has led him to ascribe to an earlier date a phenomenon for which the first evidence comes from the nineteenth century.

Females taking an oath of perpetual virginity and subsequently acquiring recognition, at least to some extent, as males were until quite recently not uncommon in the

*This text is a revision of a paper presented at the conference 'History in Anthropological Research', Mook, The Netherlands, 10-11 April 1987. Additional fieldwork data were gathered during the summers of 1987 and 1988 among the Catholic Albanian minority in Montenegro, Yugoslavia. Translations of quotations are mine. Toponyms within the borders of the Albanian state are as far as possible rendered in present-day Albanian (in the indefinite). (RG) 
western Balkan peninsula, especially among the patriarchal highland tribes of Montenegro and adjacent North Albania. ${ }^{1}$ Although this phenomenon was by no means restricted to Roman Catholics - it also occurred among Muslims and Serbian Orthodox - most information about it concerns Franciscan missionaries working among the Ghegs or North Albanians, and it is with these that the present article is concerned.

The combination of virginity and cross-dressing, the former often conceived of as a supreme form of moral purity and the latter of immorality, may already provoke astonishment; even more surprising is the involvement of clergy with cross-dressing individuals. As the old Testament clearly stipulates, 'The woman shall not wear that which pertainth unto a man, neither shall a man put on a woman's garment: for all that do so are abomination unto the Lord thy God' (Deuteronomy 22: 5). In this article I endeavour to determine the extent of the involvement of the Franciscan mission with the 'sworn virgins' of tribal North Albania, and to establish as far as possible, given the predominantly secondary and fragmentary nature of the historical material, what the mission's motives were.

I focus my attention on the second half of the nineteenth century, i.e. the period from which most relevant information stems, including the only evidence concerning ing the consecration of manlike virgins as an ecclesiastical custom. More broadly, however, I cover the whole period from the early seventeenth to the mid-twentieth centuries, i.e. from the start of the Catholic mission until the banning of all religious activities by the communist Albanian regime after the Second World War.

\section{The Material}

\section{Celibacy introduced?}

The first immediate evidence of the phenomenon of female celibacy in these regions is to be found in a report of 1638 by Fra Cherubino, one of the founding fathers of the Franciscan mission in Malesi, the mountainous hinterland of the city of Shkodër. In this account the mission enthuses over what has been achieved since the arrival in 1635 of Italian friars, priests and lay brothers sent by the Holy Congregation of the Propagation of the Faith to catholicise the region.

These believers had the conception of Jews and Turks, which means that it is perceived to be a disgrace if a woman remains without a man or a man without a woman, and husband and wife without children are considered to be cursed. Nowadays many married people want to lead a chaste life; husband and wife even live together as brother and sister by mutual agreement. Some married women decide not to enter matrimony once again when their husband dies, for they want to stay free. ${ }^{2}$

To this Cherubino proudly added that some young females - in the plains as well as in the mountains - had decided to remain chaste throughout their lives. His report reflects Franciscan enthusiasm for the chaste or continent marriage and virginity as a way of life for persons who have to live 'in the world' while being 'not of this world'. ${ }^{3}$

The chastity and purity of 'sworn virgins' - supreme detachment from the laws of human nature - led the local people to attribute extraordinary powers to them. Here we encounter the sacrificial nature of virginity - virginity as an offering to the world beyond. As mediators between mankind and the divine being, female ascetics were believed to be able to contribute to the prosperity of their fellow-men. As a conse- 
quence of mortification and otherworldliness their physical strength was believed to surpass that of ordinary humans. Yielding to earthly feelings, however, menaced the virgin's power, as the following legend shows.

A virgin, so holy that she was almost a saint, had vowed to carry [a huge rock] to the church of Berisha. She carried it safely a long way. Then in the forest she heard a shepherd fluting, and looked at him and admired him. Straightaway she forgot the heavenly things on which she had fixed her mind; she dropped the rock, and when she tried to pick it up again found she had lost her miraculous strength. And there the rock stands. ${ }^{4}$

Local Franciscans will surely have built upon popular belief in the magical power of virginity.

Relying on Cherubino, the Albanian historian and enthnologist Injac Zamputi claims that female celibacy in these mountains was in fact introduced by missionaries in the first half of the seventeenth century. ${ }^{5}$ She does not regard it as impossible that Malesi harboured chastity of the ascetic Christian kind in earlier times; but any trace of this disappeared when the area fell to Ottoman rule (the conquest started in the fourteenth century). What this region did harbour prior to the arrival of the missionaries was the phenomenon of postponement of marriage. Nubile girls took an active part in warfare and raiding like men, and were probably dressed up as males as well. Zamputi's source for this is a letter of 23 October 1617 in which the adventurer 'suitan' Yahya writes as follows about Këlmend, a large, predominantly Catholic tribe of pastoralists which at that time had been at war with the Ottoman forces for more than a decade: 'Men do not marry before they are 30 years old and women not before they are 25 . Girls do not distinguish themselves from the men, and keep their hair cut short; not until marriage do they let their hair grow long.' 6

Zamputi considers it not impossible that the missionaries' success in persuading females to embrace Christian virginity and to remain unattached and chaste throughout their lifetimes was preconditioned by the existing postponed-marriage system, which allowed females to experience years of freedom beyond the realms of family and matrimony. In these circumstances virginity as a perpetual state lost most of its ascetic Christian character, and took on a secularised, active character: the virgin (virgjinéshë) we encounter in customary law who to some extent shared equality with males.

\section{An unsuccessful nunnery}

These mountains lacked any female monasteries or communes for female members of the Third Order. We have evidence of only one attempt to alter this state of affairs. The Austrian Don Ernesto Cozzi, who worked at the beginning of this century as secular priest in Great Malesi and was afterwards appointed papal legate to Albania, tells how he discovered a document in the parochial archives of the Shosh tribe. The document relates how in about 1715 girls from the neighbouring Plan tribe decided to embrace the virginal state and to dedicate their lives to the Lord, encouraged by a certain Padre Angelo da Braciliano. Eventually, a special house was apparently constructed to serve as a 'nunnery' (adunanza di monache) in Plan. However, in 1763 the community was dissolved and its building demolished on the orders of the Propaganda fide and with the approval of Pope Clement XIII. At the beginning of this century, the ruins of what was commonly called 'the house of the virgins' were clearly visible. ${ }^{7}$ 
Contemporary sources repeatedly refer to females from tribes surrounding Plan who literally fled from their marital duties. Padre Candido reported in 1740 that 'women are running away every day, even after marriage'; and Padre Bonaventura wrote that 'women are running away a grandissima furia' ${ }^{8}$ Some of these females might have sought and found refuge in this commune, which in this way might have functioned as a kind of home for battered women. The 'nunnery' most probably provided a counterweight to the austere patriarchal culture of the tribes, an expression of female resistance to male power and the custom whereby parents arranged marriages. The unrestricted proliferation of permanent virginity among females would, however, threaten the hierarchical order and the natural reproduction of the population. The missionaries would presumably be well aware of this, and would restrain their zealous pursuit of brides for Christ out of their fear of alienating the male part of the population. ${ }^{9}$

Cozzi describes what happened after $1763 .{ }^{10}$ The papal decree concerning the Plan 'nunnery' forbade its members to live together and ordered them to return home to lead a chaste life there. Many of them continued to oppose being given in marriage, however, and continued to regard themselves as nuns. They dyed their dresses black and girded them with pink cords like the Poor Clares used to do, provoking much consternation among their people. The missionaries' efforts to convince them to abandon their unusual dress appeared to be of no avail. Instead of returning to womanhood, they went to church and took a vow of perpetual chastity during mass. This 'religious custom' (uso religioso), Cozzi states, was lost as time went on; among the mountain people of his day no trace of it was left.

\section{Consecration of manlike virgins}

In the mid-nineteenth century the distinguished albanologist and Austrian consul in Greece, Johan Georg von Hahn, mentioned the existence of females in the Pulat bishopric (small Malesi): '[die] sich durch das Gelübde der Ehelosigkeit Gott geweiht [haben]', and he added that they lived 'entweder für sich, oder dienen in fremden Häusern'." Later he was the first to report that unmarried females were actually engaging in cross-dressing. On the visit he paid to Mat and other mountainous regions belonging to the archbishopric of Durrës in 1863, he wrote:

Am meisten dürfte sich jedoch der Leser gleich dem Verfasser von einem dem Erzbisthum eigenthümlichen echt albanesischen Institute überrascht finden. In Albanien giebt es keine katholischen Frauenklöster. Gleichwohl aber zeigte sich unter den albanesischen Jungfrauen der Drang zum jungfräulichen Leben. Um nun diesem unter einem kriegerischen Volke entsprechen zu können, vertauschen sie ihr Geschlecht mit dem männlichen, indem sie männliche Kleider anlegen, sich die Haarflechten abschneiden, einen männlichen Namen annehmen und die landesüblichen Waffen führen, bestehend in Flinte, Pistolen und Jatagan [short Turkish sword]. Dieser Wechsel findet aber unter dem Schutze der Kirche statt [emphasis added], und es wird in allen Pfarreien nach dem Gottesdienste der versammelten Gemeinde Feierlich bekannt gemacht, daß die betreffende Jungfrau sich zu einem jungfräulichen Leben entschlossen, einen männlichen Namen angenommen habe und dem zu Folge in Zukunft als Mann zu betrachten sei. ${ }^{12}$

He doubted 'ob es in dem Bereiche der Katholischen Kirche sich irgend sonst wo ein 
ähnlicher Brauch finde oder jemals gefunden habe'. ${ }^{13}$

Later sources speak of the involvement of the local church with manlike virgins in other parts of North Albania as well. There is frequent reference to Mirdite, a large tribal federation belonging to the Lezhë diocese. Describing the various techniques by means of which Catholicism tried to enlarge its influence in Turkish North Albania, the Serbian author Branislav Nušić, who as vice-consul in Kosovo visited Albania in 1894 , asserted that in the recent past clergymen had introduced a 'particular kind of nun' as an antidote to the accepted practice of arranged marriages. The church tried to give girls the opportunity to remain outside wedlock. Nušić describes the actual ceremony:

The girl goes to the priest who cuts her hair, celebrates a mass, dresses her in male attire, and gives her a male name. When the service is over the priest solemnly informs the attendants why such and such a girl has decided to remain virginal and what name she has chosen, and that henceforth everyone has to consider her a male. This male carries a gun afterwards and is - a Catholic nun. ${ }^{14}$

Nušić ascribes a much more active role to the priest than does von Hahn. What is more, whereas von Hahn is apparently referring merely to the consecration of an existent indigenous custom, Nušic is explicitly claiming that it is a new practice introduced by the Catholic Church. Nušić gives no hint of having personally gathered any new material regarding this ritual, however. Like his contemporaries who also make mention of it, Nušić seems to rely on von Hahn's authority; eyewitness accounts appear to be completely nonexistent. ${ }^{15}$

\section{Drifting apart}

Cozzi deemed it necessary eventually to deny that secular 'virgins' still enjoyed the special support of the local church:

Concerning the protection the church provides to these virgins [vergini], it is necessary to note that it does not exceed the protection the church offers all its other sons, since the girl's declaration to remain virginal is fully made in the privacy of the family and never in church [emphasis added]. ${ }^{16}$

Furthermore, he denied that a declaration of virginity (dichiarazione di verginità) had anything in common with a vow of chastity (voto di castità). ${ }^{17}$ Unlike genuine nuns, these 'virgins' were not bound to chastity by an oath which had an obligatory force upon the church. As far as the church was concerned, 'virgins' could live chastely ever after, but were not obliged to do so. ${ }^{18}$ In spite of this, the 'virgins' of the mountains were often referred to by fellow-countrymen, whether in jest or seriously, as 'nun' (murgéshè). ${ }^{19}$

Albanian Catholicism experienced a strong revival in the last quarter of the nineteenth century, and this had its influence on the life of women. In increasing numbers they decided to renounce the world by embracing monasticism of the tertiary kind. Jules Degrand, French consul in Shkodër from 1893 to 1899, writes as follows:

La jeune fille catholique albanaise... peut se faire monaca [tertiaire]; quand elle a declaré qu'elle renonce à se marier, et veut être monaca, la jeune fille est libre de sortir, d'être présente pendant les visites faites à ses parents, chez lesquels elle continue à habiter, et sa condition semi-religieuse 
est indiquée par son habillement d'où les bijoux, les hautes broderies et les couleurs voyantes sont rigoureusement proscrits; elle est astreinte à trois maigres par semaine: les mardi, vendredi et samedi, à la lecture de diverses prières, dernière obligation dont elle s'affranchit assez généralement. Comme rang elle passe après sa mère et a le pas sur ses belles-soeurs. ${ }^{20}$

In the vicinity of Shkodër these secular tertiaries were soon to give way to regular ones, a development apparently closely linked to the establishment of religious foundations for women. In the early years of the twentieth century Tyrolese Poor Clares (Stigmatics) opened a nunnery in this city. Ten years after Degrand, Cozzi mentions the city harbouring numerous nuns, all dressed in black and wearing black shawls (scialle). In a declaration of 1910 the leaders of the Catholic community in Shkodër prescribed that henceforth all females who wanted to become nuns had to leave the parental home and enter a nunnery. ${ }^{21}$ This directive was apparently widely ignored, however.

By the early twentieth century 'sworn virgins' from Catholic tribes were widely accepted by missionaries as servants. Mary Edith Durham writes that "As a rule, in all districts, the sworn virgin became servant to one of the priests, and others joined the Third Order of St Francis. Some became nuns or worked in one of the Scutari [Shkodër] nunneries.'22 Franciscans gained a reputation for encouraging girls to become sworn virgins. ${ }^{23}$ Some travellers who visited the tribes in the early twentieth century encountered cross-dressing virgins sitting in the company of priests like many men used to do, ${ }^{24}$ which seems to indicate that they were on good terms.

There is virtually no evidence of excommunication of sworn virgins for engaging in cross-dressing. On the contrary, Franciscan friars seem to have continued to endorse their extraordinary social status, although no single consecration of a manlike virgin in ecclesia is reported to have occurred after the $1870 \mathrm{~s}$. For outsiders it was strange to experience the casualness with which these virgins expected to be treated as males.

Some years ago a Jesuit friar sitting in the confessional box reserved for males saw a lad approach, put his gun in the corner and kneel down. He then declared: unë jam vajzë [I'm a maiden]. She was not to be quietly prevailed upon to take the confession in the box intended for females - she claimed it to be her right and duty to do it in the male way! ${ }^{25}$

Conducting field work in Tuzi (Montenegro) I found out that the last two remaining cross-dressing virgins of this large Albanian community, Mri Djekina Ujkiq (1892-1968) and Tonë Tomja Bikaj (1901-71), were known to have been very devout persons and to have been on good terms with the priests of the local Franciscan parish. When they died they were buried in male dress, with the knowledge of the officiating priest. The information provided to me in Tuzi by relatives of the deceased was confirmed by the old parish priest Fra Marstijepaj, who was educated in pre-war Albania, and his learned curate Dr Vinko Malaj. Both men were, however, embarrassed at seeing their order associated with such an 'eccentric' practice as crossdressing by women, and insisted that their order had never had anything to do with it. They said that the Franciscans had only occasionally initiated women who embraced the rules of the Third Order by means of a small and modest ritual in church. ${ }^{26}$ When I quoted von Hahn and others on the ecclesiastical initiation of sworn virgins, they stated firmly that this was misinformation based on misinterpretation by ignorant foreigners. Their own responsibility, so they said, concerned only the few Poor Clares who lived in their own community in the parish, and the afore- 
mentioned members of the Third Order. Fra Marstijepaj spoke slightingly of an elderly woman in his parish who had proclaimed herself to be sworn virgin (though without engaging in cross-dressing) and who had had the word 'virgin' carved on her tombstone. According to the priest the word 'virgin' may be used only by women bound by monastic vows.

\section{Analysis}

In order to understand Franciscan involvement in this area we need to consider several topics: customary marital law; customary law of succession; ecclesiastical attitudes to virginity; and ecclesiastical attitudes to cross-dressing.

\section{Customary marital law}

An early testimony to the church's dissatisfaction with prevailing marriage practices among the mountain tribes is a report written in 1702 by Vincentius Zmajević, the archbishop of Bar.

Among the execrable customs of the mountain people, the wretched parents are in the habit of buying young girls for a price for their sons who are of tender age, and of keeping them in their houses till the age to cohabit, and of omitting to contract matrimony unless a male child be born, even after fifteen years of sinful cohabitation. ${ }^{27}$

Zmajević wrote these lines in his capacity as Visitator Apostolicus Albaniae. Pope Clement XI subsequently charged him with convening an ecclesiastical assembly of the Albanian province. This first Albanian Council, held in 1703 near the city of Lezhë, aimed to implement the regulations of the Council of Trent (1545-63), which had officially made matrimony the last of the seven holy sacraments: consecration by a priest has since than been indispensable if a marriage is to be legitimate according to Canon Law, and the consent of both parties has been required. Under the heading 'De sacramento matrimonii' the Council required clergy to ascertain the consent of both the prospective bride and the prospective groom, and anathematised practices such as capturing brides, using physical force and setting up trial marriages of the kind mentioned above. ${ }^{28}$ Over the next two centuries attempts by priests to bring local Albanian nuptial customs into line with these prescriptions had but little success, however. In the first decade of the twentieth century Mary Edith Durham could still write that

[The] custom of not marrying legally [in church] till a male is born is not yet extinct... All marriages are arranged by the elders, usually before the parties have reached maturity, and in a very large number of cases they have married before they had time to make a choice. Marriage is entirely by purchase, except for the occasional forcible capture of a girl. . Most of the children are betrothed in infancy or in early childhood. Some even before birth. 29

It is most likely that these mountains have for centuries harboured a minority of females who have refused to submit themselves to imposed marriages. Those who did not manage to avoid an imposed marriage often deceived their husbands or even tried to kill them. The resulting bloodshed, in its traditional form of feuding between the male members of the families and larger social units involved, was often, therefore, an unintended side-effect of prevailing nuptial practices which failed to account for female self-determination. ${ }^{30}$ 
The Kanuni i Leke Dukagjinit is the main body of North Albanian customary law which was collected and codified in the early twentieth century by the Franciscan friar Sht jefën Gjecovi (d. 1929). Whereas Article 42 of this law states that a youth is entitled to refuse unconditionally to marry the girl proposed by his family, the next article forbids a girl, under penalty of death, to abandon her proposed betrothed. With her parents' approval, however, she can avoid the wedding by promising to remain unmarried. Though her initial betrothed might marry another woman, she remains attached to him and is not to be asked for in marriage. Only he can set her free. If he does not allow her to marry, she has to wait until his death. ${ }^{31}$ Becoming a 'sworn virgin' was therefore the only respectable option for a girl who refused to get married, and the only way of avoiding a subsequent blood-feud between the families concerned. In von Hahn's days such a 'virgin' subsequently adopted masculine dress and habits: 'Ein solcher Geslechtswechsel ist ... das einzige Mittel für ein Mädchen, um sich von einem Verlöbniß loszusagen und ihre Angehörigen von der Blutrache der Familie des verschmähten Bräutigams zu bewahren.'32

Now, if Zamputi is right to claim (see above) that permanent sworn female celibacy was introduced by Franciscan missionaries, the above-mentioned provision from customary law is most likely to be a result of their intervention. Not only will it have furthered their aim of promoting a chaste lifestyle and of making loyal servants; it will also have served their policy of limiting endemic feuding, since much of the internal violence was provoked by females who refused to submit to the rigid customs concerning engagement and marriage. Two of the main goals of missionary activity in tribal Albania - 'Christianisation' of customary nuptial law and the confinement of the rampant practice of feuding - were thus intimately connected.

Until the 1880s the Franciscans in Albania were often working in harsh and difficult circumstances. They had to cope with tribalism on the one hand and with Turkish administration on the other. Of a mission operating under such unfavourable conditions one can hardly expect a strict observance of the rules. For the sake of mere survival, these missionaries had to adopt and make concessions to local practices. The Albanian mission thus applied itself to altering, or rather to mitigating, native marital law in favour of female rights. From the outset, a more radical approach would have appeared unsuitable: it would have caused too much discord with males, and hence apostacy and conversion to Islam, a religion more strongly buttressing male interests. Although the missionaries most probably preferred matrimony to be contracted on the basis of the consent of both parties concerned, their practical policy could hardly be expected to pursue dissolution of all arranged betrothals at any cost. They would restrict their intervention to the most unjust cases only.

\section{Customary law of succession}

The profusion of 'virgins' in the first decades of the twentieth century was linked not only to marriage resistance and religious calling. The Montenegrin ethnographer Andrija Jovičević relates their number to the inability of daughters of well-to-do parents without male heirs to attract husbands. Tribal law did not allow females to inherit real estate but the legal system of the newly established Albanian state did allow them to do so. However, despite their often grinding poverty, males from the mountains did not condescend to contract a marriage in which the wife provided the property. Their male pride prevented them from doing so. 'A rich wife', the expression ran, 'buys the gun with which she rules.' Many of these rich girls, Jovičević continues, did not want to abandon their patrimony and remained as 'nuns' until death. ${ }^{33}$ 
One might expect that material self-interest - the expectation of receiving property - would be one of the leading motives for servants of the church to promote sworn virginity among rich females; but I have seen no evidence of bequests of real estate to the church, though minor ante mortem donations in money or kind are in some cases indicated.

\section{Ecclesiastical attitudes towards virginity}

Throughout the period we are concerned with, Catholicism in tribal North Albania was mainly, in some parts even exclusively, represented by the followers of the great mystic St Francis. The mendicant order he founded has a long tradition of preaching renunciation of the world, most notably by promoting continence in sexual matters. The Franciscan mission in Albania had an involvement in promoting enduring chastity among women, as Fr Cherubino's seventeenth-century report, cited above, clearly indicates.

Now, although the Catholic Church perceives celibacy as a higher and finer state than marriage, it is not suitable for everyone, but only for those who are called to that state. St Paul writes that celibacy is not to be imposed on others (1 Timothy 4: 3 ; cf. 1 Corinthians $7: 25,28,37$ ). However, forced celibacy (most notably in the form of oblating children to monasteries) did creep into Christianity as it developed, and was not banned until the Council of Trent, which stated that celibacy was to be grounded in an individual's free will. The Jesuit Order was particularly involved in implementing this and other decisions of the Council. These circumstances may well have contributed to the fact that the local Franciscans increasingly dissociated themselves from those 'sworn virgins' whose motivation to remain unwed was primarily secular in nature, and began to confine their endeavours to the minority of sisters with a genuine religious vocation.

\section{Ecclesiastical attitudes towards cross-dressing}

Cross-dressing as both a practical and a symbolic device for females in pursuit of independence and moral integrity in a men's world is certainly not restricted to the western Balkans or to recent centuries - it was known to early Christianity and scattered instances of it can be traced in different parts of Christian civilisation throughout its history. In the early years of Christianity it was common for a predilection for otherworldliness to induce females to exchange feminine for masculine dress: the former was associated with vanity and seductiveness, while the latter was considered to be more modest. St Thecla is said to have abandoned her betrothed to follow St Paul dressed as a man; St Margaret fled on her wedding night in manly garb to become a monk under the name of Pelagius; and St Uncumber was saved from being given in marriage to a pagan king when she suddenly grew a beard.

Some theological justification for this tendency can be found. The gnostic Gospel of Thomas tells us that

Simon Peter said to them, 'Let Mary go forth among us, for women are not worthy of the life.' Jesus said, 'See, I will lead her that I may make her male, so that she may become a living spirit like you males. For every woman who makes herself male shall enter the kingdom of heaven.' 34

Of much greater importance for mainstream Catholic teaching, however, are statements by two Latin Fathers of the Church of the fourth and fifth centuries. St 
Ambrose, who was a fervent champion of the then emerging monasticism within the western church, wrote that

She who does not believe is a woman, and should be designated with the name of her sex, whereas she who believes progresses to perfect manhood, to the measure of the adulthood of Christ. She then dispenses with the name of her sex, the seductiveness of youth, the garrulousness of old age. ${ }^{35}$

And St Jerome, though opposing castration of males for religious purposes, declared:

As long as a woman is for birth and children, she is as different from man as body is from soul. But when she wishes to serve Christ more than the world, then she will cease to be a woman, and will be called man. ${ }^{36}$

Since monasticism was at the outset an exclusively male domain, females sometimes disguised themselves as males (or rather eunuchs) in order to enrol. Several managed to pass as monks and appear to have been devoted ascetics. Some, however, seem to have trifled with chastity. The fabulous story of the female pope Joan may serve as an example. Posing as a monk, John Angelicus by name, she was elected pope in the ninth century. The exposure of this legendary imposter is said to have occurred when she gave birth amidst a procession.

The church was eventually to try to ban female cross-dressing altogether. The Mosaic prohibition on cross-dressing (quoted earlier) was later supplemented by St Paul's plea for a clear distinction in hairstyle and head-dress between males and females (1 Corinthians 11:4-6, 14-15). Together these texts constitute the dogmatic foundation for statements by several Councils of the Church on female crossdressing.

If any woman, under the pretext of leading an ascetic life, change her apparel, and instead of the accustomed habit of women take that of men, let her be anathema. ${ }^{37}$

This provision of the fourth-century Council of Gangria was accompanied by an interdiction on short haircuts. ${ }^{38}$ The Council of Ver, some half a millennium later, expressed a similar though somewhat more lenient view:

If women who choose chastity in the cause of religion either take on the clothes of man or cut their hair, in order to appear false to others, we resolve that they should be admonished and criticised, because we consider that they err through a great ignorance rather than zeal. ${ }^{39}$

In spite of all this, cross-dressing continued to exercise an attraction for virgins dedicated to God but residing in the world, as the story of Joan of Arc shows. This young heroine of early fifteenth-century France was executed on charges of having engaged in sorcery and cross-dressing. Some 500 years later, however, Pope Benedict $\mathrm{XV}$ authorised her canonisation. ${ }^{40}$ By supporting or permitting the cults of crossdressing female saints, the church appears to have neglected its own interdictions. It was willing to condone cross-dressing insofar as it was instrumental in safeguarding the cardinal virtue of chastity. In any case, the church was much more rigorous in its repudiation of transvestism in males, for this was associated with sexual immorality. Moreover, by dressing and behaving as females, the 'lords of creation' were considered to be abasing themselves. From the point of view of the ecclesiastical authorities, males who become womanised in this way constituted a much more severe 
offence against the divine natural order than virilised females. By living chastely as males, the latter were regarded as having overcome the supposed weakness of their sex.

These perceptions were of course perfectly in keeping with the customs of the tribal society of the western Balkans. Generally speaking, cross-dressing was the obvious device whereby unmarried females could participate actively in the clear-cut male spheres of social and economic life. Their masculine dress symbolically expressed their renunciation of marriage and womanhood, and in everyday life safeguarded them to at least some extent from sexual liberties, assault, rape and abduction by males. ${ }^{41}$ At the beginning of the twentieth century, when most Albanian 'virgins' were of the non-cross-dressing type, ${ }^{42}$ it was especially those who spent long periods far away from home with the herds who had to rely on cross-dressing. Even the Jesuit Cordignano could approve of this:

Parents are afraid that a girl of marriageable age will not be able to maintain her integrity and will hence call down the danger of feuding [pericolo di sangue] upon her family. 'How would you' - thus they argue - 'keep your purity from the age of 17 till 40 ? And who will protect you against the rapist when your relatives pass away?' Under the circumstances in the mountains this reasoning is very much appropriate; in particular this holds true for those who spend the winter in the plain..$^{43}$

\section{Concluding Remarks}

Female celibacy among the tribes we are considering probably came into being as a result of a Franciscan 'break-in' to native customary law on behalf of females who wanted to remain chaste and unmarried. This type of female celibacy then received its particular character by adaptation to local practices: the customs of swearing oneself to virginity and of cross-dressing. Once established, this practice, religious in origin, was to slip out of the Franciscans' control and become increasingly profane.

It seems that for a long time - if not from the very start - the Franciscans entertained serious doubts as to whether marriage refusal, a negative motivation, sufficed to assure enduring chastity of the worldly 'virgins'. It was a risky business for the church to be associated with unmarried females whose doings and dealings could not be controlled: should they turn out to be false ascetics, a slur would be cast on their own reputation and on that of the entire church. The local priests were in the end willing to carry responsibility only for those few 'virgins' who indeed had a genuine religious calling. In the first decades of this century such 'virgins' were compelled to enter the newly founded female religious institutions in Shkodër or were taken directly under the wings of village priests.

A decreasing involvement with worldly 'virgins' did not come about only because the Fransciscans had learned by bitter experience, but also - and probably more importantly - because they had to justify themselves to the more straightforward, orthodox Jesuits, newcomers in tribal Albania and strongly protected by Rome. At the same time, Austria-Hungary was substantially increasing its financial support for the Franciscan mission. Partly as a result of improved facilities, and partly because of the decay of tribal organisation, the mission became a real power in the region. Farreaching adaptation to local culture therefore became less necessary and from the point of view of foreign supervision less acceptable as well. At about the same time the organisation of the Franciscan Order in general experienced important changes. 
In 1883 Pope Leo XIII-who was himself a member of the Franciscan Third Order-provided a new constitution for the secular members of the Third Order, and ten years later this was followed by a reorganisation of the First Order itself. The relevant enactments were all aimed at extending control and discipline. During Leo's pontificate (1878-1903) the ecclesiastical consecration of manlike virgins in Albania was banned, as well as a practice which was common in Italy but was now deemed similarly 'unnatural': the employment of castrati in church choirs.

Notwithstanding growing Franciscan aloofness towards the worldly Albanian 'virgins', however, they continued to be easily associated with one another. Whether the friars liked it or not, these 'virgins' were to a certain degree their natural allies, inasmuch as both groups were committed to celibacy. Friars and 'virgins' were outsiders in a society obsessed by marriage and procreation. According to the standards of that society, the friar was not a genuine man, nor the 'virgin' a real woman. The fact that the friars were unarmed and wore robes whereas the 'virgins' could wear trousers and carry arms highlights the marginal position they shared in this tribal society.

\section{Notes and References}

1 For an exploratory article on this phenomenon, partly based on biographical material gathered from field work in Montenegro and Kosovo, Yugoslavia, see R. Grémaux, "Mannish women of the Balkan mountains: preliminary notes on the "sworn virgins" in male disguise, with special reference to their sexuality and gender-identity', in Jan Bremmer (ed.), From Sappho to de Sade: Moments in the History of Sexuality (London and New York, 1989), pp. 143-72.

2 Quoted in Injac Zamputi, 'Pozita shoqnore e grues malësore shqiptare sipas kanunit, Buletin i universitet shtetëror të Tiranës, Seria shkencat shoqërore, vol. 15, no. 2, 1961, pp. 101-32, here pp. 120-1, 131 .

3 Apart from its monastic divisions, the male First Order of St Francis and the female Second Order of St Clare, the Franciscan community includes a lay or Third Order intended for males and females who for one reason or another (old age, marriage etc.) are unable to be professed as full monastics. These tertiaries serve the friars and help them to disseminate their teaching.

${ }^{4}$ Mary Edith Durham, Some Tribal Origins, Laws and Customs of the Balkans (London, 1928), p. 195.

5 Zamputi, op. cit., pp. 119-21. Zamputi's colleague and fellow-countryman Abaz Dojaka has more recently contended the same (Abaz Dojaka, 'La rupture du mariage', Ethnographie Albanaise, vol. 10, 1980, pp. 1-25).

6 Zamputi, op. cit., p. 119.

7 E. Schulz, 'Albanisches Mannweibertum', Die Woche, vol. 9, no. 40, 5 October 1907, pp. $1758-63$, here p. 1763.

8 Durham, Some Tribal Origins..., p. 193.

9 Felix Kanitz reports an interesting parallel from the small Bulgarian Roman Catholic minority (Pavlikani). In the mid-1870s the peasants of villages near Nikopol came into conflict with the foreign, Austrian-paid local clergy (Passionists and Fathers of the Sacred Heart). One of the peasants' complaints concerned the withdrawal of many young females from the labour and marital market when they became servants of the church and adopted celibacy. Appealing to the Ottoman administration and threatening the foreign priests that they would convert to Eastern Orthodoxy, the revolting peasants demanded, among other things, that 'girls who decide to become nuns are no longer to live in the village, but have to enter a monastery'. Felix Kanitz, Donau-Bulgarien und der Balkan: Historisch-geographisch-ethnographische Reisestudien aus den Jahren 1860-1879 (2nd ed, 3 vols, Leipzig, 1882), here vol. II, pp. 37, 42-4. 
10 Ernesto Cozzi, 'La donna albanese con speciale riguardo al diritto consuetudinario della Montagne di Scutari', Anthropos, vol. 7, 1912, pp. 309-35, here p. 320.

11 Johann Georg von Hahn, Albanesische Studien (3 vols, Jena, 1854), here vol. I, pp. 183, 209 .

12 Johann Georg von Hahn, 'Reise durch die Gebiete des Drin and Wardar, Nachrichten der philosophisch-historischen Classe der $K$. Akademie der Wissenschaften, vol. 15, no.2, 1867, pp. 1-188, here p. 31 .

13 Von Hahn, 'Reise durch die Gebiete...', p. 32.

14 Branislav Nušić, S Kosova na sinje more: Beleške s puta kroz Arbanasa 1894 godine (Belgrade, 1902), pp. 81-2.

is We may note some interesting similarities with the story of St Clare of Assisi, founder of the Second Order of St Francis. In 1212, at the age of 18, she resisted her father's wish that she get married. She managed to flee and took shelter in St Francis' newly founded commune. When she took her solemn vows, St Francis is said to have cut off her hair. This story will surely have been disseminated among Catholic Albanians by the Franciscan missionaries, and might have induced indigenous girls to act likewise.

16 Cozzi, op. cit., p. 320-21n.

17 Compare 'Ein besonderes Gelübde ist mit diesem Wechsel [from female to male] nicht verbunden' (von Hahn, 'Reise durch die Gebiete...', p. 31); and 'Das Gelübde der vor der von der Sippe abgegebenen Jungf rauschaft ist für die Kirche gänzlich unverbindlich. Es ist reine Privat- und Familiensache, das nur so lange besteht, als es den Virtschen [virgin] passt, hat also mit dem Gelübde der Nonne nichts zu tun.' (Schulz, op. cit., p. 1762).

18 Cozzi, op. cit., p. 321.

19 Compare Mary Edith Durham, High Albania (London, 1909), p. 57.

20 A. T. (Jules) Degrand, Souvenirs de la Haute-Albanie (Paris, 1901), pp. 31-32.

2 Cozzi, op. cit., p. 321. This attempt to put an end to the phenomenon of stay-at-home nuns resembles what occurred some 40 years earlier among Catholic Bulgarians (see note 9).

22 Durham, Some Tribal Origins..., p. 195.

23 Tihomir R. Djordjević, 'Zavetovane devojke kod Arbanasa', in Djordjević, Naśs narodni zivot (vol. VI, Belgrade, 1932), pp. 62-5, here p. 64.

24 Karl Steinmetz, Ein Vorstosz in die nordalbanischen Alpen (Leipzig and Vienna, 1905), p. 50; Durham, High Albania, p. 85.

25 Giuseppe Valentini, 'La famiglia nel diritto tradizionale albanese', Annali laternanensi, vol. 9, 1945, pp. 9-212, here pp. 29-30n.

26 Marijana Gušić, 'Pravni položaj ostajnice-virdjineše u stočarskom društvu regije Dinarida', in Odredbe pozitivnog zakonodavstva i običajnog prava o sezonskim kretanjima stočara u jugoistočnoj Evropi kroz vekove (Belgrade, 1976), vol. IV, pp. 269-95, here p. 275.

27 Mary Edith Durham, 'High Albania and its customs in 1908', Journal of the Royal Anthropological Institute of Great Britain and Ireland, no. 40, 1910, pp. 453-73, here p. 459.

28 Georg Stadtmüller, 'Das albanische Nationalkonzil vom Jahre 1703', Orientalia christiana periodica, vol. 23, 1956, pp. 68-91, here p. 80.

29 Durham, 'High Albania and its customs... ', pp. 458-9.

30 Steinmetz, op. cit., p. 17; Durham, High Albania, p. 198.

31 Shtjefën Gjeçovi, Kanuni i Lekë Dukagjinit (Shkodër, 1933), p. 14.

32 Von Hahn, 'Reise durch die Gebiete...', p. 31.

33 Andrija Jovičević, 'Plavsko-gusinjska oblast, Polimje, Velika i Sekular', Srpski etnografski zbornik (Belgrade), vol. 21, 1921, pp. 383-587, here p. 438; Jovičević, 'Malesija', Srpski etnografski zbornik, vol. 27, 1923, pp. 1-149, here p. 96.

34 Quoted in Vern L. Bullough, Sexual Variance in Society and History (New York and London, 1976), p. 186.

35 Marina Warner, Joan of Arc: the Image of Female Heroism (New York, 1982), p. 148.

36 Warner, loc. cit. 
37 Ernest Crawley, Dress, Drinks and Drums: Further Studies of Savages and Sex (London, 1931), p. 154.

38 Marie Delcourt, 'Le complexe de Diane dans l'hagiographie chrétienne', Revue de l'histoire des religions, vol. 153, no. 1, 1958, pp. 1-33, here pp. 21-2.

39 Quoted in Warner, op. cit., p. 152.

40 In her fine study of Joan of Arc, Marina Warner depicts her as an unorthodox mystic who was neither nun nor member of the Third Order (op. cit., p. 93). This opinion runs counter to the one expressed by A. de Gourlet: 'On sait que toutes les probabilités s'accordent pour rattacher Jeanne d'Arc au tiers ordre de saint François; en tout cas elle ne peut être comptée que parmi les vierges dédiées a Dieu...' (A. de Gourlet, Les Vierges Chrétiennes: Etude historique (Paris, 1909), p. 42.

41 Gusić, op. cit., pp. 275-6.

42 According to Schulz, the predominantly Catholic tribes of Malesi counted about 200 'virgins' in 1907; between 10 and 15 of them were completely dressed as males, some carried arms as well; the vast majority wore female clothing with as sole marker of their special status a white çalma (scarf wrapped around the head) like that of men. (Schulz, 'Albanisches Mannweibertum', p. 1760.)

43 Fulvio Cordigano, L'Albania a traverso l'opera e gli scritti di un grande missionario italiano il P. Domenico Passi S.I. (1847-1914) (3 vols, Rome, 1933-4), here vol. I, pp. 110-11n. 